\title{
Subjective assessment of post-operative pain in patients hospitalised in surgical wards
}

\section{Subiektywna ocena bólu pooperacyjnego u pacjentów hospitalizowanych na oddziałach zabiegowych}

\author{
Monika Łabuzek ${ }^{1}$, Aneta Grochowska ${ }^{1}$, Maria Mika ${ }^{1}$, Karolina Wojtaszek² \\ 'Department of Nursing, State Higher Vocational School, Tarnow, Poland \\ Head of the Department: Monika Łabuzek \\ 2Department of Anaesthesiology and Intensive Care, Health Care Facility, Dębica, Poland
}

Medical Studies/Studia Medyczne 2019; 35 (2): 100-107

DOI: https://doi.org/10.5114/ms.2019.86328

Key words: pain, postoperative pain, pain assessment scales, pain pharmacotherapy.

Słowa kluczowe: ból, ból pooperacyjny, skale oceny bólu, farmakoterapia bólu.

\begin{abstract}
Introduction: Postoperative pain treatment should be aimed at: relieving the sick, avoiding the physiological effects of pain, and preventing psychological complications such as anxiety and fear.

Aim of the research: The analysis of the postoperative pain felt in patients hospitalised in surgical wards.

Material and methods: The research made use of the diagnostic survey method using survey techniques. The research tool was the author's questionnaire and the McGill Pain Questionnaire (R. Melzack). The research was conducted in December 2015 and January and February 2016 on a group of 100 patients of the Health Care Facility in Dębica from the General Surgery and Trauma Surgery and Orthopaedics wards. The survey was completed voluntarily and anonymously. Calculations were made using SPSS software. The level of significance adopted was $p<0.05$.

Results: On the second day after the surgery, the patients defined their pain most often as light (39\%) or mild (34\%), 17\% identified pain as average, $5 \%$ as strong, and $5 \%$ of patients did not feel pain at all. Seven per cent of patients did not notice any relief after the administration of painkillers, in half of the patients the painkillers helped to overcome the pain, and $43 \%$ of those surveyed felt partial relief.

Conclusions: One should pay more attention to the issue of post-operative pain. More time should be spent talking with the patient in order to explain the surgery proceedings. Despite widespread use of painkillers, pain is felt by the majority of patients after surgery.
\end{abstract}

\section{Streszczenie}

Wprowadzenie: Leczenie bólu pooperacyjnego powinno mieć na celu przyniesienie ulgi choremu, uniknięcie fizjologicznych następstw bólu oraz przeciwdziałanie powikłaniom psychologicznym, takim jak lęk i strach.

Cel pracy: Analiza odczuwanego bólu pooperacyjnego u pacjentów hospitalizowanych na oddziałach zabiegowych.

Materiał i metody: W badaniu zastosowano metodę sondażu diagnostycznego z użyciem ankiety. Narzędziem badawczym był autorski kwestionariusz ankiety oraz Arkusz doznań bólowych (The McGill Pain Questionnaire R. Melzack). Badanie przeprowadzono w grudniu 2015 roku oraz styczniu i lutym 2016 roku u 100 pacjentów Zakładu Opieki Zdrowotnej w Dębicy z Oddziału Chirurgii Ogólnej oraz Oddziału Chirurgii Urazowej i Ortopedii. Ankieta była wypełniana dobrowolnie i anonimowo. Do obliczeń użyto programu SPSS. Przyjęto poziom istotności $p<0,05$.

Wyniki: W drugiej dobie po zabiegu chirurgicznym pacjenci najczęściej określali ból jako lekki (39\%) lub łagodny (34\%), 17\% określiło ból jako średni, 5\% jako silny, a 5\% pacjentów w ogóle nie odczuwało bólu. Siedem procent pacjentów nie odczuło ulgi po podaniu środków przeciwbólowych, połowie chorych leki przeciwbólowe pomogły w zwalczeniu bólu, a 43\% badanych poczuło częściową ulgę.

Wnioski: Należy zwrócić większą uwagę na zagadnienie bólu pooperacyjnego. Powinno się poświęcić więcej czasu na przeprowadzenie rozmowy z pacjentem w celu wyjaśnienia mu postępowania pooperacyjnego. Mimo powszechnego stosowania środków przeciwbólowych ból występuje u większości chorych po zabiegach chirurgicznych. 


\section{Introduction}

Pain is a natural reaction of the human organism to damaging factors. Despite the development of medical sciences, post-operative pain is still perceived as one of the basic problems of patients that has a direct and harmful impact on human physiology and psyche [1].

After surgery, each patient feels pain, which is an experience that is individually felt and interpreted by the patient. Properly conducted pain therapy shortens the time of hospitalisation, reduces treatment costs, and has a beneficial influence on the patient's well-being [2].

The treatment of post-operative pain should begin before the surgery, during anaesthetic consultation. At that time, the patient should be informed about the methods of pain treatment that can be used in the patient's case. After the surgery, an interdisciplinary team should engage in pain treatment, and such treatment should involve: pain assessment, pain treatment, and reassessment of pain and treatment effects. This requires good cooperation between the anaesthesiologists, surgeons, and nurses who take care of the patient before, during, and after the surgery [1].

This thesis discuses the issue of post-operative pain and the scales on which it can be assessed.

\section{Aim of the research}

The objective of this thesis was to analyse the type and level of post-operative pain suffered by patients hospitalised in surgical wards.

\section{Material and methods}

The research was conducted in the Health Care Centre in Dębica in the following wards: General Surgery as well as Trauma Surgery and Orthopaedics within three months, from December 2015 to the end of February 2016. The population studied consisted of patients who agreed to the survey, were at the surgical ward on their second post-operative day, and were able to read, write, and fill in the questionnaire by themselves. The questionnaire were given at an optimum time of the day with an explanation of how to fill it in. The respondents who participated in the survey were informed about the anonymity and objectives of the study, and their right to refuse to participate in the study or to withdraw their consent to participation at any time, without any consequences. After giving their informed consent, they filled in the questionnaires. The ratio of returned questionnaires amounted to $100 \%$.

The method of a diagnostic survey with the use of questionnaire was employed as the research method. The research tools included the author's own questionnaire and the McGill Pain Questionnaire by R. Melzack [3].
The questionnaire contained questions referring to socio-demographic factors, taking painkillers, and their effectiveness after surgery.

The MPQ was developed in order to perform quantitative and qualitative assessment of pain sensations. It is a multidimensional questionnaire that allows one to specify the emotional aspect of a patient's sensations, enabling an overall assessment of the patient's condition while taking account of elements of psychological functioning. It is one of questionnaires that is most frequently used in specialist pain treatment clinics. It allows one to monitor the course of treatment of a patient with chronic pain, including emotional changes. This questionnaire is composed of a drawing of pain, NRS scale, and 74 adjectives referring to sensory, emotional, and cognitive evaluative aspects of pain sensations $[4,5]$.

\section{Statistical analysis}

Calculations were made with the use of SPSS software. The differences between the variables were verified by means of a $\chi^{2}$ test, Mann-Whitney test and Kruskal-Wallis test. The level of significance adopted was $p<0.05$.

\section{Results}

The studied group, including 100 people, comprised $47 \%$ women and $53 \%$ men. Average age of the studied people was $43.60 \pm 15.34$ years (Table 1 ).

Most (88\%) patients declared that they had been informed before their surgery about the pain that may occur afterwards. Twelve per cent of patients did not obtain such information. Ninety-one percent of patients received painkillers after surgery and 9\% did not receive such medications. Half of the patients who obtained painkillers after their surgery declared that the painkillers helped them with their pain. Partial pain relief as a result of administered painkillers was indicated by $43 \%$ of respondents. A group of 7\% of people declared that the administered painkillers were not effective.

The author's own studies showed that the average number of words selected by the respondents to describe their pain was $6.97 \pm 3.64$. The results ranged from zero to 20 words. Most frequently, the respondents indicated from four to seven words.

The average level of sensory characteristics of pain was $6.29 \pm 4.49$. The results ranged from zero points to 21 points. Most frequently, the respondents indicated three points and 5-6 points. The average level of affective characteristics was $0.68 \pm 1.44$ points The results ranged from zero points to eight points. The average level of evaluative characteristics was $1.82 \pm 1.69$ points. The results ranged from zero points to seven points. Most frequently, the respondents got one point. The average level of miscellaneous character- 
Table 1. Characteristics of the studied group

\begin{tabular}{|c|c|c|c|}
\hline \multicolumn{2}{|l|}{ Variable } & \multirow{2}{*}{$\begin{array}{l}N \\
47\end{array}$} & \multirow{2}{*}{$\begin{array}{l}\% \\
47\end{array}$} \\
\hline Gender & Female & & \\
\hline & Male & 53 & 53 \\
\hline \multirow{3}{*}{$\begin{array}{l}\text { Marital } \\
\text { status }\end{array}$} & Married & 70 & 70 \\
\hline & Single & 22 & 22 \\
\hline & Widows/widowers & 8 & 8 \\
\hline \multirow[t]{2}{*}{ Work } & Professionally active & 74 & 74 \\
\hline & Professionally inactive & 26 & 26 \\
\hline \multirow{2}{*}{$\begin{array}{l}\text { Type of } \\
\text { anaesthesia }\end{array}$} & General anaesthesia & 67 & 67 \\
\hline & Spinal anaesthesia & 33 & 33 \\
\hline \multirow[t]{13}{*}{$\begin{array}{l}\text { Type } \\
\text { of surgery }\end{array}$} & $\begin{array}{l}\text { Removal of implanted } \\
\text { devices from lower limb }\end{array}$ & 15 & 15 \\
\hline & $\begin{array}{l}\text { Laparoscopic } \\
\text { cholecystectomy }\end{array}$ & 13 & 13 \\
\hline & $\begin{array}{l}\text { Plastic surgery } \\
\text { of umbilical hernia }\end{array}$ & 8 & 8 \\
\hline & Debridement of wound & 7 & 7 \\
\hline & $\begin{array}{l}\text { Removal of varicose } \\
\text { veins from lower limb }\end{array}$ & 7 & 7 \\
\hline & Arthroscopy & 6 & 6 \\
\hline & $\begin{array}{l}\text { Endoprosthesis } \\
\text { of hip joint }\end{array}$ & 6 & 6 \\
\hline & Hallux valgus correction & 6 & 6 \\
\hline & Breast lump removal & 4 & 4 \\
\hline & Partial bowel resection & 4 & 4 \\
\hline & Dupuytren's contracture & 3 & 3 \\
\hline & $\begin{array}{l}\text { Plastic surgery } \\
\text { of inguinal hernia }\end{array}$ & 3 & 3 \\
\hline & Removal of skin lesion & 3 & 3 \\
\hline
\end{tabular}

istics was $2.73 \pm 2.26$ points. The results ranged from zero points to 11 points. Most frequently, the respondents got one point. The average index of pain assessment was $11.52 \pm 7.20$ points. The results ranged from zero points to 36 points. Most frequently, the respondents got results between six points and 11 points.

The average level of present pain intensity (PPI) in the respondents amounted to $1.83 \pm 0.94$ points. Five percent of respondents reported no pain. Most frequently, the patients experienced mild pain (34\%) or slight pain (39\%). Average intensity pain was experienced by $17 \%$ and severe pain by $5 \%$ of patients (Figure 1 ).

Eight percent of the patients suffered from persistent pain. In the case of $37 \%$ of the respondents, their pain was of intermittent nature. Episodic pain was experienced by more than half of the respondents (55\%) (Figure 2).

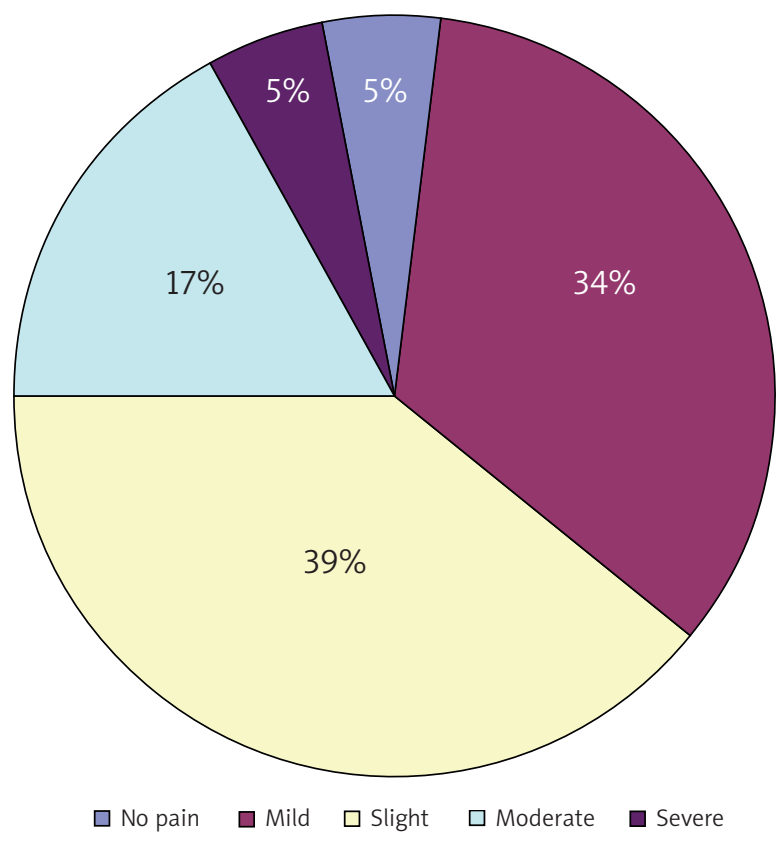

Figure 1. Present pain intensity (PPI)

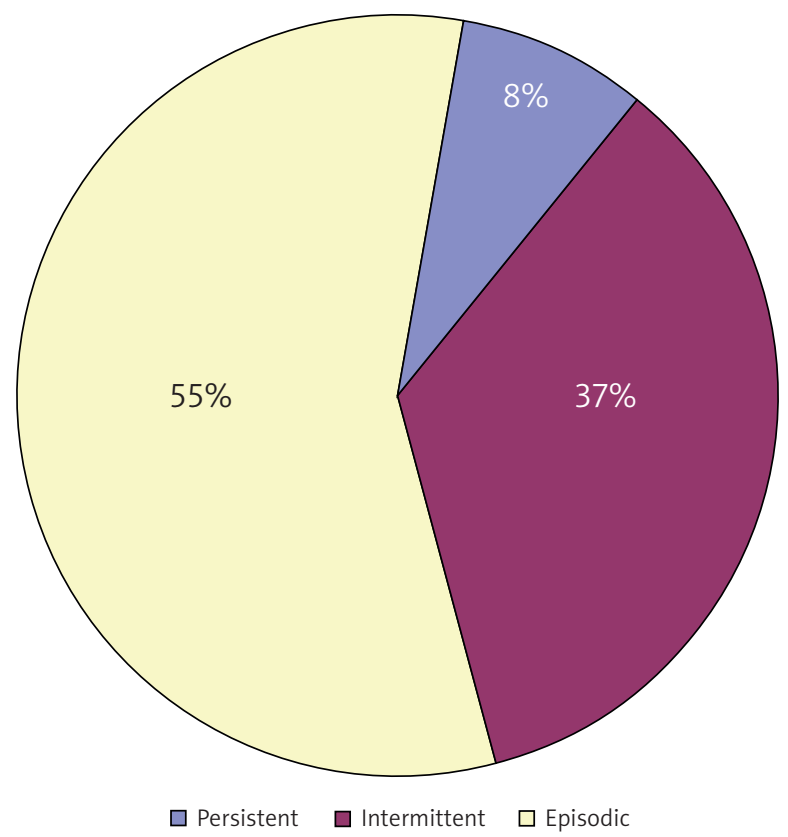

Figure 2. Pain

Most respondents (74\%) slept well. Restless sleep occurred in $22 \%$ of the patients. Insomnia was experienced by $4 \%$ of the respondents. Forty-seven percent of the patients were fully active. Limited activity occurred in $43 \%$ of the respondents. In the case of 3\% of the patients, their activity was slight, and no activity was determined in $7 \%$ of the respondents. 
Table 2. Results of pain sensation scale (McGill's scale) and respondents' age

\begin{tabular}{|c|c|c|c|c|c|c|c|c|c|}
\hline \multirow[t]{3}{*}{ Variable } & \multicolumn{8}{|c|}{ Age } & \multirow[t]{3}{*}{$P$-value } \\
\hline & \multicolumn{2}{|c|}{$20-40$} & \multicolumn{2}{|c|}{$41-60$} & \multicolumn{2}{|c|}{$61-80$} & \multicolumn{2}{|c|}{ Total } & \\
\hline & Mean & SD & Mean & SD & Mean & SD & Mean & SD & \\
\hline Present pain intensity (PPI) & 1.45 & 0.74 & 1.86 & 0.81 & 2.94 & 0.93 & 1.83 & 0.94 & $<0.0001$ \\
\hline Number of selected words (NSW) & 5.80 & 3.29 & 7.40 & 3.31 & 9.63 & 3.91 & 6.97 & 3.64 & 0.0010 \\
\hline Sensory characteristics of pain (PAI S) & 4.59 & 3.38 & 6.77 & 4.07 & 10.44 & 5.53 & 6.29 & 4.49 & 0.0002 \\
\hline Affective characteristics (PAI A) & 0.37 & 0.95 & 0.46 & 0.95 & 2.13 & 2.47 & 0.68 & 1.44 & 0.0012 \\
\hline Evaluative characteristics (PAI E) & 1.84 & 1.77 & 1.71 & 1.53 & 2.00 & 1.86 & 1.82 & 1.69 & 0.8625 \\
\hline Miscellaneous characteristics (PAI M) & 2.33 & 2.06 & 2.60 & 1.56 & 4.25 & 3.40 & 2.73 & 2.26 & 0.0930 \\
\hline Pain assessment index (PAI) & 9.12 & 5.81 & 11.54 & 5.85 & 18.81 & 9.01 & 11.52 & 7.20 & 0.0003 \\
\hline
\end{tabular}

The author's own studies showed that the patients' gender did not significantly affect the intensity of pain. Slightly higher intensity of pain was experienced by women (1.91 points) than by men (1.75 points). It was also discovered that the respondents' gender did not significantly affect the values of NSW index (number of selected words) or the PAI index (pain assessment index) and its subscales $(p>0.05)$.

The results of author's own studies showed that the respondents' age significantly affected the sensation of pain. It was discovered that with age, the intensity of pain increased. The intensity of pain in the 20-40-year-old group was 1.45 points, in the $41-60$-year-olds it was higher (1.86 points), and the most severe pain was experienced by people aged 61-80 years (2.94 points).

The analysis of the author's own studies demonstrated that with age, the NSW index increased. It was on average 5.80 points in the youngest age group, in the 41-60 age group it was 7.40 points, and the highest NSW index occurred in the 61-80 age group (9.63 points). It was determined that with respondents' age, the sensory characteristics of pain significantly increased (from 4.59 points in the youngest age group to 10.44 points in the oldest age group). Also, the values of the index of affective characteristics increased with respondents' age. These interdependencies translated into a significant increase in the pain assessment index (PAI) with age. This index in the 20-40 age group was 9.12 points, in the $41-60$ age group it was 11.54 points, and in the $61-80$ age group it was 18.81 points. It was not discovered that the patients' age significantly affected evaluative or miscellaneous characteristics (Table 2).

Respondents' marital status did not significantly affect the present pain intensity. Slight differences suggested that low intensity of pain referred to singles, higher to married patients, and the highest to widows/ widowers. A similar relation occurred in the case of the number of selected words. In both cases, the limit of significance was slightly exceeded. On the other hand, it was discovered that respondents' marital status significantly affected the sensory characteristics of pain. Lower results were demonstrated by singles (5.86) and married respondents (5.89). Higher results of PAI S were discovered in widows/widowers (11.00). Slight differences indicated that also the index of miscellaneous characteristics changed with respondents' marital status. Lower results were demonstrated by singles and the highest by widows/widowers. The studies showed significant differences in the pain assessment index and respondents' marital status. Lower results were demonstrated by singles (10.68) and married respondents (10.84), and higher results were demonstrated by widows/widowers (19.75). It was discovered that respondents' marital status significantly affected other pain indices (Table 3).

The results of the author's own studies demonstrated that higher pain intensity index occurred in persons who were professionally inactive (2.50) and lower in professionally active patients (1.59). These differences were statistically significant. Slight differences suggested also higher NSW index in professionally inactive persons (8.12) and lower in professionally active persons (6.57). Statistically significant differences occurred in the case of sensory characteristics of pain (5.54 points in professionally active persons and 8.42 points in professionally inactive persons). Also, the index of affective characteristics was higher in professionally inactive persons (1.31) and lower in professionally active persons (0.46). It was not demonstrated that the index of evaluative characteristics and the index of miscellaneous characteristics depended on respondents' professional activity. The studies showed that higher pain assessment index occurred in professionally inactive persons (15.15) and lower in professionally active persons (10.24) (Table 4).

The type of anaesthesia during the surgery did not significantly affect the sensation of pain felt by the respondents $(p>0.05)$. Slight differences suggested that a higher index of miscellaneous characteristics occurred in persons who were under general anaesthe- 
Table 3. Results of pain sensation scale (McGill's scale) and respondents' marital status

\begin{tabular}{|c|c|c|c|c|c|c|c|c|c|}
\hline \multirow[t]{3}{*}{ Variable } & \multicolumn{8}{|c|}{ Marital status } & \multirow[t]{3}{*}{$P$-value } \\
\hline & \multicolumn{2}{|c|}{ Single } & \multicolumn{2}{|c|}{ Married } & \multicolumn{2}{|c|}{$\begin{array}{l}\text { Widow/ } \\
\text { widower }\end{array}$} & \multicolumn{2}{|c|}{ Total } & \\
\hline & Mean & SD & Mean & SD & Mean & SD & Mean & SD & \\
\hline Present pain intensity (PPI) & 1.68 & 0.95 & 1.79 & 0.90 & 2.63 & 1.06 & 1.83 & 0.94 & 0.0781 \\
\hline Number of selected words (NSW) & 6.68 & 4.85 & 6.77 & 3.17 & 9.50 & 3.07 & 6.97 & 3.64 & 0.0519 \\
\hline Sensory characteristics of pain (PAI S) & 5.86 & 5.36 & 5.89 & 3.67 & 11.00 & 6.19 & 6.29 & 4.49 & 0.0494 \\
\hline Affective characteristics (PAI A) & 0.95 & 1.96 & 0.51 & 1.13 & 1.38 & 2.07 & 0.68 & 1.44 & 0.4522 \\
\hline Evaluative characteristics (PAI E) & 1.73 & 1.72 & 1.74 & 1.55 & 2.75 & 2.60 & 1.82 & 1.69 & 0.5880 \\
\hline Miscellaneous characteristics (PAI M) & 2.14 & 2.32 & 2.70 & 1.91 & 4.63 & 3.81 & 2.73 & 2.26 & 0.0777 \\
\hline Pain assessment index (PAI) & 10.68 & 8.70 & 10.84 & 5.91 & 19.75 & 8.83 & 11.52 & 7.20 & 0.0150 \\
\hline
\end{tabular}

Table 4. Results of pain sensation scale (McGill's scale) and respondents' professional activity

\begin{tabular}{|c|c|c|c|c|c|c|c|}
\hline \multirow[t]{3}{*}{ Variable } & \multicolumn{6}{|c|}{ Professional activity } & \multirow[t]{3}{*}{$P$-value } \\
\hline & \multicolumn{2}{|c|}{ Yes } & \multicolumn{2}{|c|}{ No } & \multicolumn{2}{|c|}{ Total } & \\
\hline & Mean & SD & Mean & SD & Mean & SD & \\
\hline Present pain intensity (PPI) & 1.59 & 0.77 & 2.50 & 1.07 & 1.83 & 0.94 & 0.0002 \\
\hline Number of selected words (NSW) & 6.57 & 3.42 & 8.12 & 4.05 & 6.97 & 3.64 & 0.0842 \\
\hline Sensory characteristics of pain (PAI S) & 5.54 & 3.78 & 8.42 & 5.64 & 6.29 & 4.49 & 0.0283 \\
\hline Affective characteristics (PAI A) & 0.46 & 1.10 & 1.31 & 2.04 & 0.68 & 1.44 & 0.0142 \\
\hline Evaluative characteristics (PAI E) & 1.70 & 1.58 & 2.15 & 1.97 & 1.82 & 1.69 & 0.3393 \\
\hline Miscellaneous characteristics (PAI M) & 2.54 & 1.89 & 3.27 & 3.05 & 2.73 & 2.26 & 0.6264 \\
\hline Pain assessment index (PAI) & 10.24 & 5.88 & 15.15 & 9.26 & 11.52 & 7.20 & 0.0239 \\
\hline
\end{tabular}

sia during their surgery (3.01) and lower in patients who were under spinal anaesthesia (2.15).

The author's own studies demonstrated that patients who were informed before their surgery about pain sensations that could occur after their surgery had higher index of evaluative characteristics (1.98) compared to persons who did not obtain such information $(0.67 ; p=0.0027)$. It was not demonstrated that the values of other indices significantly depended on the reception of information by the respondents about possible pain sensations after their surgery.

As a result of the author's own studies, it was determined that painkillers were administered after the surgery to persons with higher pain assessment index (11.90). In the group of patients who did not receive painkillers after their surgery, the pain assessment index was significantly lower $(7.67 ; p=0.0369)$. Slight differences suggested the same correlation in the case of sensory and evaluative characteristics of pain.

The indices of pain sensations were significantly correlated with the effectiveness of pain treatment by means of administration of painkillers to the patients. In the case of pain intensity, the NSW index, and the
PAI index and its components, higher values were demonstrated in persons who claimed that painkillers administered to them were not effective. Lower indices of pain sensations were demonstrated in patients who indicated partial effectiveness of their painkillers. The lowest indices of pain sensations were determined in persons who indicated full effectiveness of painkillers administered after their surgery (Table 5).

The author's own studies showed that the nature of pain sensations significantly affected all indices of pain sensations. Pain intensity, the NSW index, and the PAI index and its four components were highest in persons whose pain was of persistent nature. Lower values of these indices occurred in persons with intermittent pain, and the lowest ones in persons with episodic pain. These differences were statistically significant, except for the index of evaluative characteristics where the differences slightly exceeded the threshold of statistical significance (Table 6).

As a result of the author's own studies, it was determined that functioning connected with sleep significantly affected the indices of pain sensations in the respondents. Higher values of those indices were 
Table 5. Results of pain sensation scale (McGill's scale) and pain treatment effectiveness resulting from administered painkillers

\begin{tabular}{|c|c|c|c|c|c|c|c|c|c|}
\hline \multirow[t]{3}{*}{ Variable } & \multicolumn{8}{|c|}{$\begin{array}{l}\text { Pain treatment effectiveness resulting from administered } \\
\text { painkillers }\end{array}$} & \multirow[t]{3}{*}{$P$-value } \\
\hline & \multicolumn{2}{|c|}{ Yes } & \multicolumn{2}{|c|}{ No } & \multicolumn{2}{|c|}{ Partially } & \multicolumn{2}{|c|}{ Total } & \\
\hline & Mean & SD & Mean & SD & Mean & SD & Mean & SD & \\
\hline Present pain intensity (PPI) & 1.37 & 0.74 & 3.67 & 0.52 & 2.13 & 0.77 & 1.85 & 0.95 & $<0.0001$ \\
\hline Number of selected words (NSW) & 5.52 & 3.30 & 11.67 & 4.89 & 8.26 & 2.81 & 7.10 & 3.65 & $<0.0001$ \\
\hline Sensory characteristics of pain (PAI S) & 4.74 & 3.96 & 10.50 & 6.06 & 7.97 & 4.01 & 6.51 & 4.50 & 0.0001 \\
\hline Affective characteristics (PAI A) & 0.30 & 0.79 & 3.83 & 2.64 & 0.62 & 1.18 & 0.67 & 1.42 & $<0.0001$ \\
\hline Evaluative characteristics (PAI E) & 1.41 & 1.27 & 2.67 & 2.66 & 2.38 & 1.91 & 1.91 & 1.74 & 0.0344 \\
\hline Miscellaneous characteristics (PAI M) & 1.67 & 1.51 & 6.67 & 3.61 & 3.56 & 1.96 & 2.81 & 2.32 & $<0.0001$ \\
\hline Pain assessment index (PAI) & 8.13 & 5.32 & 23.67 & 9.93 & 14.54 & 5.62 & 11.90 & 7.25 & $<0.0001$ \\
\hline
\end{tabular}

Table 6. Results of pain sensation scale (McGill's scale) and pain

\begin{tabular}{|c|c|c|c|c|c|c|c|c|c|}
\hline \multirow[t]{3}{*}{ Variable } & \multicolumn{8}{|c|}{ Pain } & \multirow[t]{3}{*}{$P$-value } \\
\hline & \multicolumn{2}{|c|}{ Persistent } & \multicolumn{2}{|c|}{ Intermittent } & \multicolumn{2}{|c|}{ Episodic } & \multicolumn{2}{|c|}{ Total } & \\
\hline & Mean & SD & Mean & SD & Mean & SD & Mean & SD & \\
\hline Present pain intensity (PPI) & 3.63 & 0.52 & 2.11 & 0.77 & 1.38 & 0.68 & 1.83 & 0.94 & $<0.0001$ \\
\hline Number of selected words (NSW) & 10.63 & 4.50 & 8.27 & 3.58 & 5.56 & 2.81 & 6.97 & 3.64 & $<0.0001$ \\
\hline Sensory characteristics of pain (PAI S) & 10.13 & 4.82 & 7.92 & 4.74 & 4.64 & 3.49 & 6.29 & 4.49 & 0.0002 \\
\hline Affective characteristics (PAI A) & 2.75 & 2.96 & 0.86 & 1.40 & 0.25 & 0.73 & 0.68 & 1.44 & 0.0006 \\
\hline Evaluative characteristics (PAI E) & 2.88 & 2.64 & 2.14 & 1.80 & 1.45 & 1.34 & 1.82 & 1.69 & 0.0904 \\
\hline Miscellaneous characteristics (PAI M) & 6.63 & 2.97 & 3.03 & 1.95 & 1.96 & 1.66 & 2.73 & 2.26 & $<0.0001$ \\
\hline Pain assessment index (PAI) & 22.38 & 8.50 & 13.95 & 6.86 & 8.31 & 4.73 & 11.52 & 7.20 & $<0.0001$ \\
\hline
\end{tabular}

Table 7. Results of pain sensation scale (McGill's scale) and sleep

\begin{tabular}{|c|c|c|c|c|c|c|c|c|c|}
\hline \multirow[t]{3}{*}{ Variable } & \multicolumn{8}{|c|}{ Sleep } & \multirow[t]{3}{*}{$P$-value } \\
\hline & \multicolumn{2}{|c|}{ Good } & \multicolumn{2}{|c|}{ Restless } & \multicolumn{2}{|c|}{ Insomnia } & \multicolumn{2}{|c|}{ Total } & \\
\hline & Mean & SD & Mean & SD & Mean & SD & Mean & SD & \\
\hline Present pain intensity (PPI) & 1.47 & 0.71 & 2.68 & 0.72 & 3.75 & 0.50 & 1.83 & 0.94 & $<0.0001$ \\
\hline Number of selected words (NSW) & 6.07 & 3.21 & 8.95 & 3.00 & 12.75 & 5.44 & 6.97 & 3.64 & 0.0001 \\
\hline Sensory characteristics of pain (PAI S) & 5.23 & 3.94 & 8.73 & 4.46 & 12.50 & 5.00 & 6.29 & 4.49 & 0.0002 \\
\hline Affective characteristics (PAI A) & 0.39 & 1.02 & 1.00 & 1.35 & 4.25 & 3.30 & 0.68 & 1.44 & 0.0004 \\
\hline Evaluative characteristics (PAI E) & 1.62 & 1.47 & 2.23 & 2.09 & 3.25 & 2.50 & 1.82 & 1.69 & 0.2268 \\
\hline Miscellaneous characteristics (PAI M) & 2.08 & 1.69 & 4.00 & 2.25 & 7.75 & 2.75 & 2.73 & 2.26 & $<0.0001$ \\
\hline Pain assessment index (PAI) & 9.32 & 5.40 & 15.95 & 6.88 & 27.75 & 7.50 & 11.52 & 7.20 & $<0.0001$ \\
\hline
\end{tabular}

found in persons with insomnia, lower in persons with restless sleep, and the lowest in respondents with good sleep. In all cases, except for evaluative characteristics, those correlations were of statistically significant nature (Table 7).
The analysis of the author's own studies showed that higher intensity of pain was experienced by persons with no activity (3.29) or slight activity (2.67). Lower results were demonstrated in persons with limited activity (1.91) or full activity (1.49). In the case of 
Table 8. Results of pain sensation scale (McGill's scale) and activity

\begin{tabular}{|c|c|c|c|c|c|c|c|c|c|c|c|}
\hline \multirow[t]{3}{*}{ Variable } & \multicolumn{10}{|c|}{ Activity } & \multirow[t]{3}{*}{$P$-value } \\
\hline & \multicolumn{2}{|c|}{ Full } & \multicolumn{2}{|c|}{ Limited } & \multicolumn{2}{|c|}{ Slight } & \multicolumn{2}{|c|}{ None } & \multicolumn{2}{|c|}{ Total } & \\
\hline & Mean & SD & Mean & SD & Mean & SD & Mean & SD & Mean & SD & \\
\hline Present pain intensity (PPI) & 1.49 & 0.80 & 1.91 & 0.81 & 2.67 & 1.53 & 3.29 & 0.76 & 1.83 & 0.94 & 0.0002 \\
\hline $\begin{array}{l}\text { Number of selected words } \\
\text { (NSW) }\end{array}$ & 5.66 & 3.32 & 7.65 & 3.13 & 12.00 & 7.21 & 9.43 & 3.31 & 6.97 & 3.64 & 0.0016 \\
\hline $\begin{array}{l}\text { Sensory characteristics } \\
\text { of pain (PAI S) }\end{array}$ & 4.47 & 3.72 & 7.19 & 3.56 & 14.33 & 8.08 & 9.57 & 6.27 & 6.29 & 4.49 & 0.0003 \\
\hline $\begin{array}{l}\text { Affective characteristics } \\
\text { (PAI A) }\end{array}$ & 0.30 & 0.78 & 0.72 & 1.37 & 2.67 & 4.62 & 2.14 & 1.95 & 0.68 & 1.44 & 0.0068 \\
\hline $\begin{array}{l}\text { Evaluative characteristics } \\
\text { (PAI E) }\end{array}$ & 1.68 & 1.68 & 1.95 & 1.59 & 0.67 & 1.15 & 2.43 & 2.44 & 1.82 & 1.69 & 0.2896 \\
\hline $\begin{array}{l}\text { Miscellaneous characteristics } \\
\text { (PAI M) }\end{array}$ & 2.06 & 1.80 & 2.86 & 1.83 & 4.00 & 4.36 & 5.86 & 3.67 & 2.73 & 2.26 & 0.0138 \\
\hline Pain assessment index (PAI) & 8.51 & 5.59 & 12.72 & 5.94 & 21.67 & 14.01 & 20.00 & 9.33 & 11.52 & 7.20 & 0.0003 \\
\hline
\end{tabular}

the NSW index, higher results were demonstrated in persons with slight activity (12.00) or with lack thereof (9.43). Lower results were found in persons with limited activity (7.65) and the lowest ones in persons with full activity (5.66). Similar relations referred to sensory characteristics of pain, affective and miscellaneous characteristics, as well as the general PAI index. It was not determined that respondents' activity significantly affected the evaluative characteristics of pain sensations (Table 8).

\section{Discussion}

Post-operative pain is perceived as one of the main problems afflicting post-operative patients. The main objective of post-operative pain treatment is the improvement of patient's comfort, faster recovery, and prevention of post-operative complications [6].

The studies carried out by Grochans et al. [7] demonstrated that post-operative pain on the first day after the surgery is significantly more severe than on the third day [7]. This is also confirmed by studies conducted by Kołodziej and Karpiel [8] in which pain on the first and second day after the surgery was compared.

In author's own studies, the studied group was diversified in terms of age, place of residence, professional activity, and surgery performed, similarly as in the studies carried out by Kołodziej and Karpiel [8]. In the author's own studies, patients most frequently assessed pain as mild (34\%) or slight (39\%). In the studies by Kołodziej and Karpiel, post-operative pain was most frequently assessed between two and four points on a six-point scale [8].

The studies by Kołodziej and Karpiel confirmed that post-operative pain was more severely experienced by women [8]. Similar results were obtained in the author's own study - slightly higher intensity of pain was experienced by women (1.91 points) than by men (1.75 points).

The analysis of the author's own studies demonstrated that the type of anaesthesia during the surgery did not significantly affect the sensation of pain felt by the respondents; similar results were obtained in the studies by Grochans et al. [7].

Information on the course of post-operative pain treatment and order for painkillers should be given to the patients before their surgery, because this significantly affects the patients' satisfaction with their treatment. The studies carried out by Jałowiecki et al. demonstrated that such information significantly affects the patient's satisfaction $-75 \%$ of the respondents were satisfied with their anaesthesiologist's visit because, among other things, anaesthesiologists ordered painkillers for them [9]. However, from the author's own research it can be seen that this is not always the case; $12 \%$ of the respondents did not obtain such information. From the studies conducted by Lewandowska et al., it was reported that $96 \%$ of the respondents were informed before their surgery about the methods of pain treatment [10].

It should be noted that in the author's own studies, not all patients received painkillers (9\%). Half of the patients who obtained painkillers after their surgery (50\%) declared that the painkillers helped them with their pain. Partial pain relief as a result of administered painkillers was indicated by $43 \%$ of the respondents. A group of $7 \%$ of people declared that the administered painkillers were not effective. Similarly, in the studies carried out by Grochans et al. [7], it was demonstrated that $87 \%$ of the patients assessed their pharmacological pain therapy as satisfying. In the studies by Kołodziej and Karpiel, $88.6 \%$ of the re- 
spondents assessed their pharmacotherapy as good or very good [8].

The role of nurses in the treatment of post-operative pain should not be omitted. They should have proper knowledge as regards the assessment of pain intensity and various methods of pain treatment, and they should actively take part in the process of pain treatment. In this way they can ensure professional care and safety for the patients. Unfortunately, from the studies carried out by Knap et al. [11], it results that post-operative pain is not always properly monitored, and nurses do not have full knowledge on the extent of effects of painkillers and their side effects. On the other hand, the studies conducted by Knap and Szebla reported that nurses perform their tasks in acute pain service but they participate in too few training courses on post-operative pain treatment [12]. The studies on the patients' satisfaction from nurses' care, conducted by Baczyk et al. [13], also demonstrate that patients' assessment was the lowest as regards quantitative assessment of post-operative pain by medical staff, informing patients about possibilities of treatment, and lack of a possibility to co-decide about the course of treatment [13]. Similar conclusions regarding the necessity of educating nurses about the issues of post-operative pain, monitoring of such pain, assessment, and methods of treatment were presented by Jurczak et al. [14].

To conclude, post-operative pain constitutes a serious problem despite the developments in medicine. It requires multi-stage and interdisciplinary actions. The treatment of post-operative pain should begin as early as before the surgery in the form of a conversation with an anaesthesiologist, during which postoperative procedures should be discussed. Systematic assessments of pain as well as proper and individually selected pharmacotherapy are also of crucial importance. Another important element is systematic gaining of knowledge by self-education and participation in training courses on post-operative pain treatment by the entire medical staff.

\section{Conclusions}

Most frequently, the patients described their postoperative pain as mild or slight. Slightly higher intensity of pain was experienced by women than by men. Painkillers were administered to almost all patients after their surgery. Most frequently, the patients claimed that the pharmacotherapy used was fully or partially effective. Most patients were informed before their surgery about pain that may occur after their surgery. The type of anaesthesia during the surgery did not significantly affect the sensation of pain.

\section{Conflict of interest}

The authors declare no conflict of interest.

\section{References}

1. Ashley E, Doraiswami M. Ból pooperacyjny. [In:] Ból ostry. Bromley L, Brandner B (eds). Jarosz J (Ed. Polish edition), Wydawnictwo MediPage, Warszawa 2013.

2. Szkutnik-Fiedler D, Szałek E, Grześkowiak E. Zasady leczenia bólu pooperacyjnego. Farmacja Wsp 2003; 3: 21-29.

3. Melzack R. The McGill Pain Questionnaire Anesthesiology 2005; 103: 199-202.

4. Hawker GA, Mian S, Kendzerska T, French M. Measures of adult pain: Visual Analog Scale for Pain (VAS Pain), Numeric Rating Scale for Pain (NRS Pain), McGill Pain Questionnaire (MPQ), Short-Form McGill Pain Questionnaire (SF-MPQ), Chronic Pain Grade Scale (CPGS), Short Form-36 Bodily Pain Scale (SF-36 BPS), and Measure of Intermittent and Constant Osteoarthritis Pain (ICOAP). Arthritis Care Res (Hoboken) 2011; 63 Suppl 11: S240-52.

5. Kocot-Kępska M, Szułdrzyński K. Skale oceny bólu. Available at: https://www.mp.pl/bol/wytyczne/91404,skale-oceny-bolu

6. Paszkiewicz-Mes E. Rola pielęgniarki w leczeniu bólu po zabiegu operacyjnym. Pielęg XXI w 2011; 4: 37-41.

7. Grochans E, Hyrcza V, Kuczyńska M, Szkup-Jabłońska M, Jurczak A, Rotter I, Zaremba-Pechmann L, Karakiewicz B. Subiektywna ocena bólu pooperacyjnego u pacjentów po wybranych zabiegach chirurgicznych. Piel Chir Angiol 2011; 2: 82-87.

8. Kołodziej W, Karpiel E. Ból pooperacyjny na oddziale chirurgicznym w ocenie ankietowego badania z zastosowaniem kwestionariusza McGilla-Melzacka - doniesienie wstępne. Probl Pielęg 2008; 16: 231-236.

9. Jałowiecki P, Ruder R, Tomala A, Dziubdziela W. Ocena jakości postępowania anestezjologicznego na podstawie opinii chorych o znieczuleniu. II. Okres pooperacyjny. Anest Intens Ter 2001; 3: 149-155.

10. Lewandowska A, Filip R, Mucha M. Postoperative pain combating and evaluation of patient's satisfaction from analgesic treatment. Ann Agric Environ Med 2013; 1: 48-51.

11. Knap M, Szyrmer B, Kowalczyk-Sroka B. Poziom wiedzy pielęgniarek z oddziałów zabiegowych na temat terapii bólu pooperacyjnego. Probl Pielęg 2010; 18: 129-133.

12. Knap M, Szebla R. Rola pielęgniarek w zespołach leczenia bólu jako profesjonalnej formy terapii bólu pooperacyjnego. Stud Med 2011; 22: 39-43.

13. Bączyk G, Ochmańska M, Stępień S. Subiektywna ocena jakości opieki pielęgniarskiej w zakresie bólu pooperacyjnego u chorych leczonych chirurgicznie. Probl Pielęg 2009; 17: 173-177.

14. Jurczak A, Kiryk A, Kotwas A, Pawlik J, Celewicz A, Szkup M, Grochans E. Ocena jakości opieki pielęgnacyjnej w zakresie bólu pooperacyjnego. Fam Med Primary Care Rev 2015; 17: 107-110.

\section{Address for correspondence:}

\section{Aneta Grochowska}

Department of Nursing

State Higher Vocational School in Tarnow

ul. Mickiewicza 8, 33-100 Tarnow, Poland

Phone: +48692802566

E-mail: apea1@op.pl 